\title{
INTEGRATION IN THE CHAIN: A CASE STUDY ON THE COLLABORATION IN THE CHAIN OF A RESALE COMPANY OF PARTS FOR INDUSTRIAL EQUIPMENT
}

\author{
Inês Shinobu Chubachi \\ Federal Institute of São Paulo - Suzano Campus, Brazil \\ E-mail: ines.chubachi@hotmail.com \\ Wagner Roberto Garo Jr. \\ Federal Institute of São Paulo - Suzano Campus, Brazil \\ E-mail:w.garo@uol.com.br \\ Submission: $31 / 03 / 2016$ \\ Accept: $31 / 03 / 2016$
}

\section{ABSTRACT}

The increasing market competition makes companies seek better results, through partnerships with suppliers, and it is necessary to analyse and adapt to the requirements of customers and market. Thus, for the realization of this article, it is based on concepts of Logistics according to supply chain, intending to analyse operational processes and suggest improvements in results and competitive gains for collaboration in the chain of trade in pieces of industrial equipment company in the Greater São Paulo region. Therefore, we conducted literature searches through books and articles, as well as a case study, which in general, revealed that the supply chain of the studied company has great potential for improvement it once has modest integration actions compared to a model with a strategic focus and some deviations compared to the academic literature. Research results have shown issues such as ignorance of the subject proposed by the employees as well as the need to create alternatives to maximize the interaction between the sectors within the organization contributing more competitive solutions in addition to providing agility in the process as a whole. 
To carry out further research, it is recommended further study regarding the implementation of management information systems to improve some processes and, consequently, the outcome of that organization.

Keywords: Chain integration; Industrial equipment; Operational processes; Supply chain management.

\section{INTRODUCTION}

Analysis of the Brazilian market shows steady growth of equipment industries. We can say based on data from the IBGE (Brazilian Institute of Geography and Statistics) that the industry increased by $5 \%$ between February 2014 compared to February 2013. Driven by other sectors also influenced in general, production of machinery and equipment participated with $7.5 \%$ in performance, among other factors.

With continued growth and government incentives to increase production, companies have sought adaptations to survive in the face of these changes, leaving the competition between business units in isolation and opting for a competition among integrated supply chains.

Purpose, Logistics has been used as a very important tool for companies, with market competitiveness. The evolution of logistics methods allows the company to stand out among its competitors, requiring competitive instruments as cost value advantages.

Among other activities, Logistics involves the integration of activities, from extraction of raw materials, processing, assembling, warehousing, distribution, information flow management of customer requirements to delivery of the final product to the consumer, in order to have criteria to minimize costs and increase service levels to customers. Overall, Logistics can be understood as the use of planning and programming of the product flow throughout the supply chain.

Proper supply chain management enables effective planning efforts focusing on the core business of the organization, allowing the possibility of an efficient flow of goods and services through the integration of all logistics activities. This integration requires effective management of supply chain initiatives, encompassing not only 
DOI: $10.14807 /$ ijmp.v7i5.456

business processes, but also the relationship with customers and suppliers, seeking strategic partnerships that benefit all chain components.

In this context, the main objective of this article is presenting the theory of the chain integration through a case study and discuss it comparing to a company that sells parts for industrial equipment, located in greater São Paulo, without any system or integrated software, but with own organization and management coordinates its operational processes before the purchase and sale of industrial parts market. And with theoretical basis to compare the activities performed by the company in practice, suggesting possible improvements to its supply chain.

\section{2. THEORETICAL REVIEW}

\subsection{Logistics}

According to Dias (2010) Logistics is a system that manages and coordinates any business in an integrated and strategic way, as all activities that involve improving all available resources, with the goal of efficiency for cost, storage, flow, inventory, distribution and production of both materials, products, as information. In general, Logistics plans and manages all processes from raw material to the endcustomer consumption.

According to Sales (2015), in the newspaper Valor Econômico, Logistics industry has high expectations, it states that the vice-president of BNDES (National Bank for Economic and Social Development), Wagner Bittencourt, affirmed Logistics industry will be flagship of investments in the country in the coming years and that the development bank foresees investments of nearly $R \$ 600$ billion in infrastructure in the five-year period 2015-2019.

Thus, the sector is increasingly important for organizations and for the current market, and, as Cervi (2002), recognized as an area of great opportunities and have an increased role in business both in scope and in strategic importance.

\subsection{Supply chain}

The growth of competitiveness between companies made the strategic view of the business win new concepts where prior sectors were analysed separately and greater focus was on sales and increase profitability. Today, industries are analysed as interrelated processes, testified by the definition of Martins (2009) when 
describing the management of the supply chain as the administration of integrated logistics system of the company, using advanced technologies such as information management and operational research to plan and control a complex web of factors in order to produce and distribute products and services to customer satisfaction.

Coelho (2010) states that from the time the process began to be seen as associated activities, in which one influences the other, the supply chain idea emerged which accompanies the process from procurement of raw materials to the completion of the process with the client, taking into account that each step is one more factor to obtain the expected profitability. Thus, for the supply chain to work in a synchronized manner it is necessary for the management to be precise, with the control of all stages, always focusing on the company's strategy.

To achieve efficient management, it is necessary to understand what is the management of the supply chain within a company. According to Ballou (2004), the supply chain management is the coordination of the flow of goods and information between each member of the process to achieve competitiveness and profit for each member of the industry chain, beyond the scope of the whole organization.

The supply chain aims to seek integration between organizations of direct or indirect participation from the flow of a product or service, capturing suppliers, manufacturers, wholesalers, retailers and customers in order to provide an effective and efficient flow of goods or services through Logistics, reducing costs and adding value to the end customer (HILSDORF et al, 2009).

\subsubsection{Supply chain in small businesses}

Small businesses compared to large scaled companies, well-structured in relation to supply chain, present some differences in the way they manage the processes in this chain, Ratao and Junior Torres (2010) state that in small business, the lack of rules and written regulations and the absence, in most cases, of a clear definition of roles and tasks characterize the administrative informality that surrounds all management and business relationship activities. However, this informality originates behavioural and structural features that characterize the forms of interaction between small business and their supplier and consumer market.

The idea is reinforced by Costa et al (2010) who states that regarding the implementation of supply chain management, small businesses implement 
management unlike large companies, either for lack of resources or knowledge and skills, small businesses not fully implement the management and the focus of this implementation seems to be different, they do not focus closely on partners or on improving the performance of the chain as a whole. For small businesses it is easy to realize the implementation of management focusing on the selection of short-term partners, rather than a long-term vision for the development of a more comprehensive relationship between the partners.

\subsection{Suppliers and partners in the supply chain}

The company's relationship with its suppliers is of utmost importance once it relates to vital business processes, simplifying handling and storage activities, and as affirms Kotler (2007) that suppliers are an important link in the general system of delivering value for the customer, and partners, because they provide the necessary resources for the company to produce goods and services.

Garo Jr. (2014) states that collaboration between customers and suppliers and the transfer of knowledge and technology represents a significant gain for the chain, and how the company studied is Japanese, the same author in his research of a case study integrated into the automotive industry, it describes companies that source reinforce bonds with the supplier during the process, contributing to the objectives are achieved, which proves the long-term partnerships.

It is a relationship of mutual trust, where both sides are benefited, in which one depend on the other, help each other to survive in the competitive market of modern times, in other words, based on Martins (2009), the relationship between client and supplier is developed through a customer's operation (buyer) on its suppliers, seeking to achieve a degree of understanding and mutual trust where none exists.

Integration, as stated by Rodrigues et al (2010) have focused on exchange of information, collaboration between two parts, including employees in the processes to reduce costs and increase quality, especially in the technical development in order to make the process simpler and skilful.

In companies, the purchasing department has some traditional functions, such as selecting suppliers, negotiating and managing contracts of different deadlines, place orders on suppliers, develop a reliable supplier base and maintain good relations with them. In manufacturing, the cost of raw materials, parts, components 
etc. They represent more than half of the cost of the products, which makes it potentially very influential purchasing function in the profitability of the organization. Good negotiations mean return for the company, and purchases have turned into an area of major interest of the company. (MOREIRA, 2011, p.437).

As negotiations are directly linked to the profitability of companies, partnerships become strategic points that are increasingly gaining the attention of managers. As well as mutual trust, information sharing and long-term relationships are decisive points in the partnership process. According to Santos (2002, p. 12) a long-term relationship with a supplier makes it possible to share the business vision of both organizations, so that both parts benefit from the process, renewing this partnership constantly, increasing the performance of the provider.

\subsection{Purchases}

A comprehensive purchasing management form is a fundamental tool for a good performance of organizations, Colleti et al $(2002$, p.2) comments that it is a sector that should be analysed strategically, following the market needs, as well as holding and partnerships can bring significant gains in the process of purchases of materials.

The shopping sector, according to Garcia (2008, p.1) and Simões (2004, p.3), is no longer a routine activity and isolation, but part of the logistics process of the companies, because there is an interrelationship with all sectors of the organization, being influenced and influential factor in decision making. Thus, the sector has gained interests of organizations and gaining ground, becoming not only an act of purchasing products, as one needs to know to perform well, in order to take advantage.

Besides the possibility to obtain an advantage, the industry showed up with a great potential for increased profitability. Confirming this point, Arnold (2008, p.207) shows that potential explaining that when $50 \%$ of the sales income of the companies are aiming for the purchase of raw materials, components and supplies, through this analysis it is possible to put the sector decisive position in making profit and competitive advantage, as in a shopping process carried out accurately you can reduce the costs and thus achieve a degree of price attractive product to the customer. 
DOI: $10.14807 /$ ijmp.v7i5.456

Even though the importance of this sector, it is necessary to precisely define each step of this process. By setting this function, Ballou (2004, p.344) explains that shopping is the act that selects the sources of supply, develop procedures for applications, negotiating prices and terms of purchase, specifies the transport services to be used, and estimates the delivery times. In this case, the purchasing department coordinates with the planning of production material flow in the supply channel.

\subsection{Supply chain integration processes}

The process of supply chain integration depends on several factors, in addition to the definitions already described, it shows up as a decisive flow management process to control and consequently the productive and financial gain. Ideally, this flow of processes and information is coordinated from suppliers of suppliers, that is, manage the flow in the extended supply chain. The more control among members of the chain and the more it extends, the more efficient coordination and outcomes (SLACK et al, 2009).

Only supply chain management is possible when it clearly established its links, from there the importance of the relationship between members. As the explanation of Guerrini (2002), this relationship becomes more intense when there is the collaborative process as it is the most effective method to manage the flow of information, allowing flexibility and ability to adapt to market fluctuations, whatever the segment of the company is.

According to Slack et al. (2009) the key point to understand and establish a process of integrating efficiently supply chain is to analyse the behaviour of the entire chain, this is possible when we can analyse and control the relationships formed by individual parts. For this relationship to be formed by individual parts, the integration process becomes delicate according to Lambert and Cooper (2000), it involves organizations with different features, not only cultural reasons but technological and management development, making the successful Integration to be achieved more by cooperation between them, than the development of centralized management tool. 


\subsection{Supply chain management of small businesses}

Within the market context, small businesses also look for managing the best possible way before their capabilities and limitations. Just as it is defended by Furlanetto (2002, p.2) to address the collaborative actions of suppliers and customers as an important strategy for companies to organize and coordinate their supply chains in a manner that look like a big company, allows to develop a complementary relationship structure that is based on the interdependence and cooperation between the agents that make up a new form of coordination of the supply chain.

According to the same author (p.77 and 78), the pursuit of competitiveness is related more with the great systemic, which means going beyond company boundaries, so the logistics management must gain new dimension, trying to integrate all activities along the chain, adding that not just a member of the chain to seek operational excellence while others do the same.

Andrade and Tachizawa, $(2009, p .62)$ reveals that a striking feature of large organizations is that interact with micro and small businesses as suppliers and customers, along the production chain, which shows the importance of all the integration with your agents within the supply chain, a statement that reinforces the importance of small enterprises for business.

In addition to these other authors as Villareal Segoviano (2012) states that the operations of small and medium companies there is a particular context of advantages and disadvantages, which can consolidate or not a company at the international level; prior to this it is necessary to raise the application of Logistics to boost the exchange and consolidation of value creation in business.

\section{METHODOLOGY}

Starting from the definition of Severino (2007), for whom a survey with case study must be significant and very representative to a survey the case should be significant, so that it is able to support a generalization to similar situations, allowing inferences, there will be a case study in order to develop guidelines to structure the operational processes of a trading company of industrial parts aimed at the comparison between theory and practice the basics of integration in jail in addition to examining ways to improve collaboration among the sectors as a suggestion for the 
company in an integrated way, since it presents great market potential and timid integrative actions in their processes.

To that end, we conducted a literature review of the issues inherent in integrating the supply chain with the purpose of comparing the process described in theory and what is observed in practice by lifting routine operational process across the board of sectors the company through a notice 30 days as non-directive interviews and access to some data and information by employees, verifying that the studied company has great potential for improvement.

Because it is a case study, it seeks to explain, qualitatively, the characteristics of the studied company, based on possible sources due to lack of records, documents, statistics regarding the process and is therefore an exploratory research and nature applied.

\section{THE CASE}

\subsection{Basic features}

The company, founded in 1990, of Japanese origin, located in São Paulo, sells parts for industrial equipment as well as offers maintenance services and leases such equipment.

It serves more than 300 small, medium and large companies. It has few competitors in the region it serves, advantage that can enhance their business and competitiveness.

The team consists of about 15 people, led by a manager. Among the employees, most are mechanical while each sector is administered by one person. For being a small business, multifunctionality of administrative employees is frequent, i.e., there is a correct definition of the activities of a single sector, but there is a responsibility to meet the needs or manager requests and customers. So in addition to performing its primary function, the official also interacts with others to complete the customer service.

In the case of trade in parts, the relationship between customers, the company and its suppliers, requiring points to be improved because accommodated due to the partnership of time, the company does not bother to integrate both the information about the actions across sectors to streamline their operational processes. 
DOI: 10.14807/ijmp.v7i5.456

\subsection{Supply chain}

The company studied primarily presents the following process flow within their supply chain as shown below:

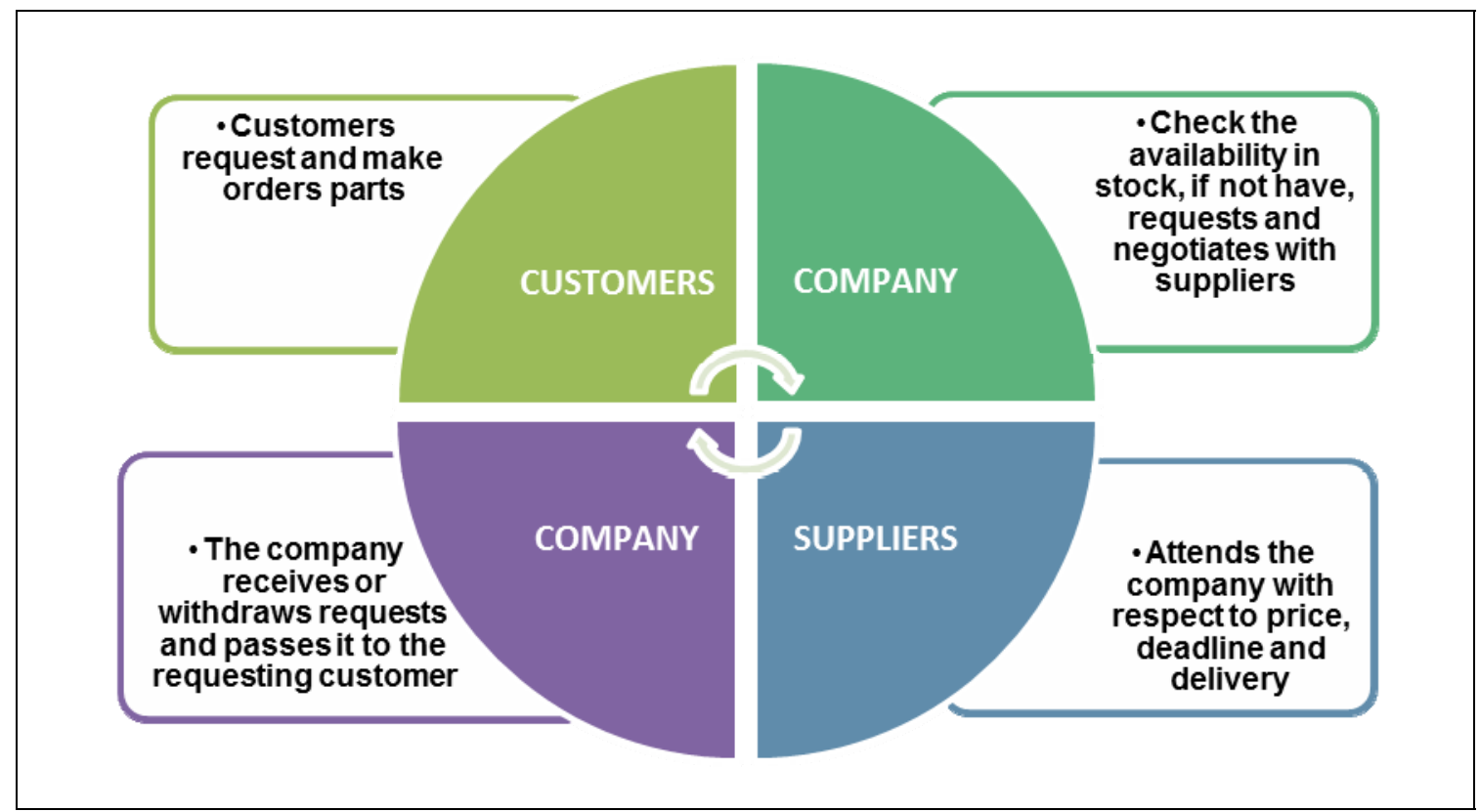

Figure 1: Company's supply chain

Source: Author, 2015.

The company's supply chain is basically composed of supplier, distributor, retail and customer. The company is an agent that mediates the purchase and sale of parts for its customers, with more than 100 suppliers for this process. By having the larger amounts by buying advantage and resell to retail customers, the goal most often for the purchase of parts is based on cost reduction when comes to quality and customer demand the purchase of parts is based on reduction risks.

The supply chain management, this company aims to reduce costs because the resale to their customers should be appealing and satisfying, as well as reducing time to acquire the necessary part without the risk of errors. For this, the dependence of both the supplier and the customer to provide information often results in a more streamlined process, when it comes to buying and selling.

In relation to other sectors of the company as a financial and reception, information and settings of some customer requirements it is critical to be shared to prevent future errors and delays, which the size of the studied company allows for each employee having a contact and understanding of function of the other, with a 
DOI: $10.14807 /$ ijmp.v7i5.456

more flexible environment and easy access to other operating processes of the organization.

\subsubsection{Cost management}

The cost reduction, risk and delivery time management are the basis for some stocks as the relationship with the supplier and customer to exchange technical information to make a purchase and surest sale, as well as the buyer with the operational staff (mechanical) and account manager and discuss the questions for decision-making.

\subsubsection{Relationship: provider and enterprise}

The company has few, however livelong alliances with some suppliers, reflecting the reliability of products and services, as well as payment and term conditions. This relationship provides ease and time savings to be straight with those who buy, as well as partnerships to maintain a connection encourages purchases through promotions and warnings about some of the product specifications. There are some cases in which the company is dependent on a few suppliers, for only some have the required part, due to the lack of exploitation of other sources decreasing the supply options.

For some to requiring a minimum billing amount and release the order, the buyer with his feedback and understanding selects and checks the stock possible pieces to add and make the request. Information is also shared with the mechanical needs and seller to such purchase.

\subsubsection{Relationship: business and customer}

The reasons that make the customer uses the company is due to performance time to market, little competition in the area and indications of other customers. So the reliability and flexibility they offer to older clients provide reliability as to order parts and information, as for being the bridge between the largest suppliers to final consumers.

In the case of the relationship between client and other sectors of business, such as financial and operational, except some cases, friendship and confidence in the client's character allows trading flexibility and priority in decisions in the sense of something late, in the case of payment or urgency in providing service. 
DOI: 10.14807/ijmp.v7i5.456

\subsubsection{Inventory}

The company works with the minimum stock, with maximum reduction of idle parts. It uses the time to reduce base to serve the customer as quickly as possible, because it is a piece of equipment that will often be stopped or maintenance can paralyze the entire production of a company. Thus, the time limit for delivering of a piece can be a couple of days, and it can vary up to 30 days, because they are imported parts.

Inventory control is performed as buyer and seller of knowledge and continuous demand for parts. It is made a steady lifting with respect to the parts in stock. The decision to purchase the most parts is made from the customer's request and exchange of information between those who have access to the sector.

\section{RESULTS AND DISCUSSION}

\subsection{Scenario of trade in pieces of industrial equipment}

In view of the current scenario and encouragement of production, which includes the machines and equipment, as well as parts were published on March 6 , 2015, two resolutions of the Foreign Trade Chamber in order to reduce the import duty 289 industrial machinery and equipment without production in Brazil. The first resolution brings 262 ex-tariff for machinery and equipment (capital goods) 187 items and renewed other 75 with reduced tax of $14 \%$ to $2 \%$ by 30 June 2016 , a situation in which motivates the trade sector pieces of industrial equipment in which the company may have studied opportunities.

As for the threats to the industry of pieces of industrial equipment, now faced by various sectors, we have the Chinese competition, which increasingly participate in the market making it more competitive thus requiring strategic planning of the companies to try to survive and face the consequent difficulties, according to Logistics Magazine (2011), which also adds the market situation that spent much of 2009 stagnated, with reduced sales by $39 \%$ due to the crisis, and in the same year, the Americas fell by $43 \%$ in sales and in 2011 . Brazil is going through an economic stability provided a growth in the area of industry and trade, thus the logistics industry and drive is getting great results. Industrial equipment's are essential tools in the logistics process, therefore, it can be said that most companies need some handling equipment as well as parts for maintenance. 
DOI: $10.14807 /$ ijmp.v7i5.456

From the data that demonstrate the positive factors to trade in industrial equipment parts, the purchasing process as well as any other department of a branch company needs to be prepared and integrated to the organization's success, so Kotler (2007, p. 322) reinforces the idea to mention that within the company, the various functional departments should work together to maximize the company's own logistics performance.

\section{ANALYSIS OF THE CASE STUDY}

The analysis of the business processes in question shows the characteristic to have a chain of immediate supplies, with few suppliers and direct contact with the customer. This feature demonstrates the ease control in some processes, for example we can mention the partnership with its long-term suppliers proposed by Santos (2002, p.12), creating a solid relationship where both are benefited. The request at least three quotations, price negotiation and delivery of goods, which prove that even without any specific and strategic planning for the sector, functions basically equate with what sets Arnold (2008, p. 221 and 224), where the purchasing department is responsible for negotiating prices that benefits both parties.

Given this observation and comparison of practice and theory, the process of integration of the studied company's supply chain is directed to activities at the tactical and operational level, i.e., has a low strategic focus. According to Santos (2002, p. 22), when there is no strategic focus, operational effort turns out to be much higher, so that the process is completed. It also reduces the accuracy of future sales prospecting, since the strategic level it is possible to establish plans and forecasts. There is no established method to manage and analyse the relationship between links in the chain, let alone see how it can enhance cooperation between them, which a vulnerable aspect is when it comes to control and real implementation of a collaboration among members of the supply chain.

The level of maturity of focus and growth in the business sector is low, because it has no pretensions to meet new clients, being accommodated with the current situation, going against the guidance of Arnold (2008, p. 220), and requires a constant evaluation of the supplier, so that you can combine technical and price. This is because most of the activities that are part of the purchasing process are not 
DOI: 10.14807/ijmp.v7i5.456

integrated and standardized. Purchasing decisions are embedded in the price and the requesting client service.

\section{CONCLUSION}

With the growing importance and the logistics industry in recent times, development opportunities also apply to those processes that are part of this sector. With this in mind, organizations prepare and create ways to survive in the face of both the market and requirements of its customers, seeking to be competitive and strategic in their business.

We can conclude that regardless of the type of company, the supply chain has the basic features described in the academic literature, which proves and operates the activities that this sector involves, but improvement is always welcome, because due to adaptations of competitors and even new businesses can make direct threats to the organization of life in the competitive market. In relation to the case study, even with a history of over twenty years in business, the company has precariousness before some processes that could be changed to maximize purchases along with the consequent billing of its sales, it is clear also that there is an integration of other sectors in which the processes are subject to the knowledge of former employees without formal knowledge, academic or its function, limiting their actions. It would be interesting training and implementation of a computerized system, as a standard and empowerment for employees, in order to enable faster flow of information, making collaboration between members more intense.

\section{REFERENCES}

ANDRADE, R. O. B.; TACHIZAWA, T. (2009) Network suppliers of production inputs companies: a socio-environmental analysis of the supply chain in the empirical research based organizations. Micro and Small Business Magazine FACCAMP, v. 3, n. 3. Available in: <http://www.faccamp.br/ojs/index.php/RMPE/article/view/68> Acess: 30/09/2015.

ARNOLD, J. R. T. (2008) Materials Management. São Paulo: Atlas.

BALLOU, R. H. (2004) Managing the Supply Chain - 5.ed.: Business Logistics. Available in:

<https://books.google.com.br/books/about/Gerenciamento_da_Cadeia_de_Suprimen tos_L.html?hl=pt-BR\&id=XTq7VgXxm5MC>. Acess: 05/05/2015.

CENSO (2010) Industrial production varies $\mathbf{- 0 . 2 \%}$ in November. Available in: $<$ http://censo2010.ibge.gov.br/noticias- 
censo?view=noticia\&id=1\&idnoticia=2559\&busca=1\&t=producao-industrial-varia-0-2novembro>. Access: 12/05/2015.

CERVI, R. (2002) Centralization of purchases as logistic strategy. The case of Magistral Pharmacies. Dissertation (Master in Production Engineering) - Federal University of Santa Catarina, Florianópolis.

COELHO, L. C. (2010) Supply Chain Management - concepts, trends and ideas for improvement. Available in: <http://www.logisticadescomplicada.com/gestao-dacadeia-de-suprimentos--conceitos-tendencias-e-ideias-para-melhoria>. Acess: 18/05/2015.

COLLETI, J. A. R. et al. (2002) The importance of purchasing management for the competitiveness of businesses: the case of super network. XXII NATIONAL MEETING OF PRODUCTION ENGINEERING, 2002. Curitiba - PR.

COSTA, A. G. (2010) The supply chain management for small and medium enterprises. XXX INTERNATIONAL CONFERENCE ON INDUSTRIAL ENGINEERING, Available in: <http://www.abepro.org.br/biblioteca/enegep2010_TN_STO_113_741_16110.pdf> Acess: 30/09/2015.

CRISTINA, L. (2015) Import tax reduction for industrial equipment is published. Available in: <http://www.ebc.com.br/noticias/economia/2015/03/reducao-deimposto-de-importacao-para-equipamentos-industriais-e-publicada>. Access: 12/05/2015.

DIAS, M. A. P. (2010) Materials Management: principles, concepts and management. Atlas: São Paulo.

FURLANETTO, E. L. (2002) Formation of coordination structures in supply chains: case studies in five local companies. Dissertation (Doctorate in Business Administration) - Graduate Program in Business Administration, Federal University of Rio Grande.

GARCIA, G. R. (2015) The importance of the purchasing function in organizations. Available in:

<http://www.techoje.com.br/site/techoje/categoria/detalhe_artigo/541>. Access: 15/05/2015.

GARO Jr., W. R. (2014) Competitive priorities and organizational innovation: a case study of integration in the automotive industry. Dissertation (Master in Production Engineering) - University of São Carlos, Sorocaba.

GRIESINGER, D.(2014) IBGE: Industry accumulates growth of $5 \%$ in one year. Available in: <http://www.ebc.com.br/noticias/economia/2014/04/ibge-industriaacumula-crescimento-de-5-em-um-ano>. Access: 10/05/2015.

GUERRINI, F. (2002) Organizational architecture in cooperation networks. In: PRODUCTION MANAGEMENT SYMPOSIUM LOGISTICS AND INTERNATIONAL OPERATIONS (SIMPOI), 5., 2002, São Paulo. Anais. São Paulo: EAESP-FGV.

HILSDORF, W. C. et al. (2009) Integration processes in the supply chain and customer service performance: a study in the footwear industry in Franca.

Production Management [online] v. 16, n. 2, p. 232-244. 
INDEPENDENT JOURNAL OF MANAGEMENT \& PRODUCTION (IJM\&P)

KOTLER, P.; ARMSTRONG, G. (2007) Marketing principles. 12 ed. São Paulo: Pearson Prentice Hall.

LAMBERT, D. M.; COOPER, M. C. (2000) Issus in supply chain management. Industrial Marketing Management, v. 29, n. 1, p. 65-83.

MARTINS, P. G.; CAMPOS, P. R. (2009) Materials Management and heritage resources. 3 ed. Saraiva: São Paulo.

MOREIRA, D. A. (2011) Production management and operations. 2 ed. São Paulo: Cengage Learning.

RATAO, B. P.; TORRES JUNIOR, A. S. (2010) Operational efficiency and relationship in the supply chain of small and medium case-study company over a small distribution company. (SIMPOI-ANAIS). Available in:

$<$ http://www.simpoi.fgvsp.br/arquivo/2010/artigos/E2010_T00306_PCN50172.pdf> Access: 30/09/2015.

LOGISTICS MAGAZINE (2011) Available in:

$<$ http://www.imam.com.br/logistica/noticias/servicos/258-distribuidores-deempilhadeiras-mais-proximos>. Access: 02/05/2015.

RODRIGUES, E. F. et al. (2010) Analysis of supply chain integration: a case study of private hospitals in small and medium size in São Paulo. XXX NATIONAL PRODUCTION ENGINEERING MEETING. Available in: $<$ http://www.abepro.org.br/biblioteca/enegep2010_TN_STO_113_741_15168.pdf>. Acess: $12 / 05 / 2015$.

ROMILDO, J. (2013) IBGE reports that there was a decline in industrial activity in May. Available in: <http://www.ebc.com.br/noticias/economia/2013/07/ibgeinforma-que-houve-queda-na-atividade-industrial-em-maio>. Acess: 11/05/2015.

SALES, R. (2015) Logistics will be the flagship in the coming years, affirms BNDES. Available in: <http://www.valor.com.br/brasil/4044754/logistica-serra-carrochefe-nos-proximos-anos-diz-bndes>. Access: 12/05/2015.

SANTOS, A. P. L. (2002) Shopping process of structuring materials to enable the implementation of electronic commerce in the construction industry. Dissertation (Master of Engineering) - Technology Sector, Federal University of Paraná, Curitiba.

SEVERINO, A. J. (2007) Methodology of scientific work. 23 ed. rev. e updated. São Paulo: Cortez.

SIMÕES, É. M. M. (2004) Purchasing management the importance for organizations. School of Legal Studies and Management of Garça.

SLACK, N.; CHAMBERS, S.; JOHNSTON, R. (2009) Planning and Control Supply Chain. 3 ed. São Paulo: Atlas.

VILLARREAL SEGOVIANO, F. J. (2012) Integrated Logistics: An alternative to create value and competitive advantages in small and medium enterprises (SMEs) in the footwear sector. Nova scientia, v. 4, n. 8. Available in:

$<$ http://www.scielo.org.mx/scielo.php?script=sci_arttext\&pid=S2007-

07052012000200010\&lng=es\&nrm=iso>. Access: 30/09/ 2015. 